\title{
The ethics of absolute relativity: An eschatological ontological model for interpreting the Sermon on the Mount
}

Author:

Andre van Oudtshoorn ${ }^{1}$

Affiliation

${ }^{1}$ Department of the Dean of Academics and Research,

Perth Bible College, Australia

Correspondence to:

Andre van Oudtshoorn

Email:

andre@pbc.wa.edu.au

Postal address:

56 Lilburne Road, Duncraig,

WA6023, Australia

\section{Dates:}

Received: 11 June 2013

Accepted: 28 Oct. 2013

Published: 12 Mar. 2014

How to cite this article: Van Oudtshoorn, A., 2014,

'The ethics of absolute relativity: An eschatological ontological model for interpreting the Sermon on the Mount', Verbum et Ecclesia 35(1), Art. \#883,

7 pages. $h$ ttp://dx.doi. org/10.4102/ve.v35i1.883

\section{Copyright:}

(C) 2014. The Authors.

Licensee: AOSIS

OpenJournals. This work

is licensed under the

Creative Commons

Attribution License.
Jesus' imperatives in the Sermon on the Mount continue to play a significant role in Christian ethical discussions. The tension between the radical demands of Jesus and the impossibility of living this out within the everyday world has been noted by many scholars. In this article, an eschatological-ontological model, based on the social construction of reality, is developed to show that this dialectic is not necessarily an embarrassment to the church but, instead, belongs to the essence of the church as the recipient of the Spirit of Christ and as called by him to exist now in terms of the coming new age that has already been realised in Christ. The absolute demands of Jesus' imperatives, it is argued, must relativise all other interpretations of reality whilst the world, in turn, relativises Jesus' own definition of what 'is' and therefore also the injunctions to his disciples on how to live within this world. This process of radical relativisation provides a critical framework for Christian living. The church must expect, and do, the impossible within this world through her faith in Christ who recreates and redefines reality. The church's ethical task, it is further argued, is to participate with the Spirit in the construction of signs of this new reality in Christ in this world through her actions marked by faith, hope and love.

\section{Introduction}

Christian ethicists have long battled with the absolute character of Jesus' demands in the Sermon of the Mount and how these may and should apply in the ever-changing cultural context in which believers find themselves. This tension clearly relates to the problem with the Biblical text - that it has 'an inexhaustible hermeneutical potential' (Hays 1996:1). As Richard Hays points out, careful exegesis of the Biblical text may only exacerbate the problem by heightening our awareness of the cultural difference between us and the context of the text as well as the ideological diversity that may be found amongst the various writers of the Bible (Hays 1996:3). In order to make sense of our exegesis, we need a broader integrative framework within which to interpret the meaning and significance of our exegesis.

In this article, I propose an integrative theological-hermeneutical model to help Christians engage meaningfully with the text of the Sermon on the Mount. There have been many attempts at devising an intra-textual or intra-canonical theological framework to help us understand the Biblical text. Whilst none of these Biblical theological frameworks, such as salvation-history, promise and fulfilment and the covenant, on their own have succeeded in providing a final integrative framework for the Bible as a whole, they have all proven useful in bringing some coherence to a number of seemingly divergent texts. They did this by exposing the theological presuppositions which may have operated in the original context to create meaning for the original author and the readers. Whilst the Biblical-theological frameworks help us to understand the world of the text, a hermeneutical approach is required to create a similar meaning within different contexts. Such a hermeneutical approach implies a critical analysis of the cultural constructs and dominant ideology operating within any particular context which may influence the relevance of, and meaning created from, the text by readers. It also implies devising ways of replicating the relevance and meaning of the first context into the new. The difficulties we experience in dealing with the imperatives within the Sermon on the Mount, however, transcend both these standard approaches. The radical injunctions of Jesus seem to stand in a place of its own. Who can truly live by giving to anyone who asks things of them? Who can relinquish all self-defence? Who can live without being concerned about what they will wear or eat? Who can be truly perfect? These questions become even harder when we apply them to governments and society as a whole. Can we truly live without a police force that will use violence to apprehend murderers and rapists? Can a Christian king really give everything away because people from other nations may ask it of him? What sets the imperatives of the Sermon on the Mount apart, however, is not the mere fact that they are seemingly difficult, if not impossible, to obey today but that they must 
already have seemed impossible to obey within the original communication situation in which they were first given to Jesus' disciples and to the first readers of the gospels. The imperatives of the Sermon on the Mount call for a critical theological analysis of Jesus' underlying understanding of reality that forms the basis for his injunctions. This understanding is so much at odds with the underlying ontology informing a variety of cultural definitions of reality across time and place. I will propose a dialectic model of relative absolutes and absolute relativity based on the different ontological presuppositions that may form the basis from which an ethical framework for Christian living in this world may be developed, an ethical framework that does justice to both the radical demands of Jesus and the reality in which we find ourselves. Because the church encounters the injunctions of Jesus as part of a text, it is important to consider the theological function and role of the Biblical text for the construction of an alternative interpretive reality by which to live in this world. The construction of interpretive realities takes place in the context of a cultural paradigm. For this reason, we shall briefly consider the inter-relationship between culture, texts and the Bible before discussing the Sermon on the Mount and constructing an alternative ontological model for understanding Jesus' imperatives.

\section{Cultural definitions of reality}

According to Berger and Luckmann (2011:50-63), humans produce society in response to a biological need to order their existence and keep it from falling into chaos. This society, as an externalising of their subjective consciousness, becomes an objective reality which, in turn, has the power to shape the world of the individual. Hans Georg Gadamer has pointed out that no one can ever stand apart from reality and interpret it objectively (Gadamer 2004). We are, on the contrary, always subjectively involved in the process of interpretation in that we always interpret reality in terms of our everyday experiences. These everyday experiences can, for their part, only be interpreted in the light of certain presuppositions (or assumptions) that we hold about reality. ${ }^{1}$ Our presuppositions concerning reality are, for their part, formed by the tradition in which we find ourselves. Tradition, again, is the result of a historical and on-going inter-personal discussion about reality and how it is to be interpreted. In the final analysis, according to Gadamer, our interpretation of the world is always mediated by history and our relationships with other people.

This mediating inter-personal relationship by which we interpret reality can be defined as culture. ${ }^{2}$ Laurence Kincaid (1987:15) describes culture as an open system, comprising of a communicational network of relationships which facilitates the

1.Erving Goffman (1974) has pointed out that what is real for us is determined by our definition of the situation.

2.There are of course many definitions of culture. The cultural anthropologist Cyril Hally (as quoted by Don Edwards 1996) stated that there are more than 250 definitions of 'culture' in anthropology. As definitions are always the result of a specific, underlying meta-theory, we shall proceed to develop our own definition here in terms of certain communicational and theological presuppositions. Paul G. Hiebert (in Dorr et al. 1999:C9) defines culture as the integrated system of learned patterns of behaviour, 1999:C9) defines culture as the integrated system of learned patterns of behaviour,
ideas and products characteristic of society which also presupposes such inter-personal ideas and product
relationships. exchange of information. ${ }^{3}$ The more information ${ }^{4}$ is processed within a group, the more the group will also be drawn together or converge, and ipso facto, the less information being processed, the more divergence there will be within the group. Extensive convergence leads to a common worldview, beliefs, values and behaviour, which Lloyd Kwast (in Dorr, Graham \& Koch 1999:C3-C6) describes as the basic layers of culture. These 'cultural layers' form the broad framework (or cultural paradigm) by which individuals organise experiences to finally make sense of reality and the events in everyday life.

Berger and Luckmann, in their book The Social Construction of Reality (2011), agree with the premise that all interpretations of reality are finally determined by social forces. They take this insight somewhat further, however, by pointing out that interpretation is always the product of interaction in a particular time and place and in a particular social milieu. As a result, our understanding of events also changes as our particular social context changes. Even if we stay in one place, our social context still changes through time. But how does the movement of 'time' influence our interpretation of events? In this regard, insights from the Centre for Contemporary Cultural Studies at Birmingham, which stress the point that 'particular' social contexts usually function as the bearers of particular ideologies may help us. Stuart Hall (2004), the leader of the movement in Birmingham, argues that culture is never static or homogeneous but, rather, in a constant state of flux. This, according to Hall, results from the fact that, within any particular culture, multiple ideologies exist side by side in dynamic tension with each other. ${ }^{5}$ Rather than just viewing culture as simply existing, we should rather see culture as dynamic and changing - being constantly produced anew through a struggle for cultural dominance amongst different sets of ideologies. Cultural dominance by any particular ideology is always a temporary phenomenon, which explains the fact that cultural changes take place over time.

These insights enable us to define culture more closely as a progressively changing inter-relationship of small, specific, inter-personal communication clusters (or sub-cultures), each with its own cultural variations and ideological agendas, but each of whose deviation from the presently generally accepted, cultural standard is not large enough for it to be construed as a counter-culture. The diachronic informational inter-change and inter-play between various sub-cultures eventually result in a different general cultural standard being recognised and a distinctly new culture developing. ${ }^{6}$

3.In systems theory, open systems are those in which new information are processed and they are thus open to change and adaptability. Closed systems, in contrast, have no inter-change with its environment which inevitably leads to the disintegration of the system. In this sense, Kincaid is following the work of Peter Monge (1987, in Berger, Roloff \& Ewoldsen 2009:239-270), 'The network of analysis' who describes networks as groups that are connected to one another through a process of communication.

4.It is generally recognised that 'information' is not the only contributor to group convergence. Giles, Coupland and Coupland (1991:1-68) pointed out that convergence is also facilitated by perceptions of power and the search for approval.

5.For a discussion, see Littlejohn and Foss (2008:235).

6.There are obviously many other definitions of culture. If we focus on behaviour, for instance, culture can be defined as a cluster of cooperative behaviours. In this definition, the individual, through his or her small group inter-action, is, thus, a determining factor in the formation of culture. The structuralist view, in which reality is defined in factor in the formation of culture. The structuralist view, in which reality is defined in
terms of an objective supra-personal structure and in which man is nothing more than terms of an objective supra-personal structure and in which man is nothing more than a temporary, relational element, is thus denied without, thereby, denying the fact that
humans, in turn, are co-determined by the objective supra-personal structure that they create, live within and sustain. 


\section{Culture, text and interpretation}

So far we have dealt with culture as a living, ever-changing structure in which new information is constantly generated and absorbed. In examining the role of texts in this process of cultural formation, we find a hermeneutical circle. Texts are the products of particular socio-cultural contexts and are able to function as the carriers of deviant ideological perspectives which can challenge the dominant culture. In order to so, however, texts must be able to transcend their own immediate socio-cultural contexts and world-views and participate within the dominant culture. The further a text is able to transcend its own particular context, or in other words, the more and longer it can be used as a relevant ideological tool in the ideological battle for cultural dominance, the more the text will grow in stature. The more it grows in stature, however, the more it will function in the service of the dominant culture which grants it its relevance and the less it is, therefore, able to challenge the dominant world-view. The text loses its own 'life' and becomes more and more reliant on the use to which it is put in the ideological struggle for dominance. It is prone to obscurity, unless utilised by being granted relevance. ${ }^{7}$ The text, thus, has become 'frozen' or 'fossilised' speech (parole parlee), a passive potential rather than an active participant (parole parlante) in the ideological debate of cultural formation. In this sense, Derrida (in Bloom 2004:84) is correct in arguing that the text is a 'complex network of unfinished meanings'.

Paul Ricoeur (1976) sees the interpretation of texts as the movement between explanation and understanding. Explanation is empirical and analytical and always deals with the text as text. In the process of explaining, the exegete, therefore, searches for patterns, repetitions, et cetera in the text in order to define the limits of possible meanings that can be deduced from the text. ${ }^{8}$ In contrast, understanding, according to Ricoeur, is the process by which the interpreter gives meaning and significance to the text as a whole in the light of the interpreter's own life-world. We can, thus, describe understanding as the conscious evaluation of the potential of a text to function as an ideological tool in the cultural life-world of the interpreter.

The socio-cultural rootedness of the text demands 'explanation' and, thus, objectifies and distances the text from the reader whilst the quest for significance renders the text vulnerable to the ideological power of the dominant culture of the reader.

\section{Culture, text, scripture and interpretation}

Turning to Scripture, we have to ask ourselves whether the same pattern can also be applied to the Biblical text. In other words, to what extend does the Bible lose its own voice and ability to challenge the dominant culture. Karl Barth (2004)

7 .'Utilised' refers to the act of understanding the text to be of ideological significance.

8.Because explanation only concerns itself with the text, it can be described as a synchronic or text-immanent activity, a term used in South African structural or rhetorical analysis, which stresses the importance of surface structure literary analysis of the text. has made the point that the Bible, as the Word of God, is never given to us as an object, an ideological tool that we can manipulate and use at will. We can, of course, and often do treat the Bible in exactly the same way as any other text, that is to serve our own ideological agendas. ${ }^{9}$ But, then, according to Barth, we are not really dealing with the Bible as the Word of God.

What designates the Bible as the Word of God is the fact that the Spirit uses it as his instrument to focus our attention first of all on Jesus who alone is the Word of God..$^{10}$ Failing to recognise this dynamic movement towards Jesus, the true Subject of the Bible, Barth (2004) argues, turns the Bible into something that it is not, that is, just another text rather than the acknowledged Word of God. ${ }^{11}$ In philosophical terms, we can say that, for Barth, Jesus is the sole ontological reference point of the Bible. This means that Jesus is the only One who truly exists as the Word of God. The Bible, thus, does not have existence and meaning in, of and for itself. Scripture always refers us to a subject beyond itself - to Jesus who alone is the Word of God. ${ }^{12}$ To put it somewhat differently yet again: The Biblical text is not a depository of meaning but rather a mediation of meaning. ${ }^{13}$ The Bible can neither be explained objectively nor understood subjectively in order to generate meaning for today. It can only be explained and understood in faith as the instrument of Jesus, its true subject, who graciously chooses to use it as his message to the reader.

This means that the Bible's authority is a derived authority. It only functions with authority in the church because in and through its message the church encounters Jesus. At the same time, however, it must be recognised that the church can know and worship no other Jesus than the Jesus she meets through the message of the Bible. There is no other way to encounter Jesus than through this contextually structured interpretation of him. To stress this point, the church has always confessed the divine inspiration of the Biblical text. When the confession of the divine inspiration of the Bible, however, is divorced from its relationship to Jesus, who alone is the absolute truth, theology often falls prey to literal fundamentalism in which the human and contextual elements in Scripture are ignored. Jesus, as the final and absolute truth, does not annul the truth claims of the Bible. The Bible retains its truth value, but it is a truth value that is relative to the absolute truth found only in Jesus.

9. Barth is quite adamant that Biblical hermeneutics is not essentially different from any other form of hermeneutics. For Barth, the subject matter of the text should determine our understanding of the text. It is only when the freedom of the Subject of the Bible (Jesus Christ) is not recognised that Biblical and general hermeneutics of the Bible (Jesus Christ) is not recognised that Biblical and gene
have to part company (see Provence in McKim 1999:241-262).

10.Conservative evangelical scholars have always felt that this implies a relativisation of the Biblical text as the Word of God and that is thus totally unacceptable. Many of these same scholars would, however, agree with the statement that the Christian faith encompasses more than just having information about Jesus but, rather, having a personal relationship with him.

11.Note Barth's insistence on prayer as the prime hermeneutical tool (see Provence in McKim 1999:241-262).

12.The universal hermeneutical rule applies that a text can be read, understood and expounded only with reference to and in the light of its object (Barth 2004:546). We can, perhaps, describe the Bible as the door through which the Spirit leads us to come to know Jesus.

13.Gadamer as referred to by Dockery (2000:168). 
Whilst on earth, Jesus operated exclusively in terms of his own definition of reality - a definition that did not accommodate the ontological broken structure of the world in any way. Jesus operated with the definition of a perfect world of love, joy, peace and wholeness - a world reshaped in and through his presence to be part of the Kingdom of God. It is to be noted that where the world or given reality resisted this new definition of it, Jesus did not change his definition of reality - he changed reality! This process can be described in terms of speech act theory as a 'world to word fit'. In the same way as the declarative statement, 'I now pronounce you man and wife', changes reality in the light of the words that are uttered, so too did Jesus' declaration (and his actions in the light of that declaration) about the in-breaking of the Kingdom of God in this world change the world around him. This explains the purpose behind the various miracles that we find recorded in Scripture. The world becomes different in the light of the presence of the absolute truth. The world has to change, be transformed, to fit into this new authoritative definition of reality. Jesus' death on the cross is seen by Paul as the ultimate counter-cultural act of the absolute Lord by which he condemned and destroyed the broken world as it existed in opposition to God. In this act, Jesus, once and for all, did away with the old age, the old reality, the old cultural paradigms as it existed - and still exists for us and we for it - and inaugurated the eschatological new age in which we participate through the Spirit and according to which we are now called to understand and redefine our world. All culturally constructed truth claims have an ontological substructure: They are grounded in existence, and they are an ultimate definition and explanation of what 'is'. Berger and Luckmann (2011:87-88) describe four stages in constructing such a cultural 'world'. In the first stage, the world is described objectively. In the second stage, presuppositions and basic theories to support that reality are developed. In the third stage, specific theories (domains of knowledge) are created, and in the fourth stage, a symbolic universe is developed. The symbolic universe, as Geertz (quoted in Fager 1993:91-94) pointed out, is based on shared meaning that transcend the everyday world and that is not always directly experienced by the individual. These meanings are transmitted through the symbolisation of objects, persons and events which are able to convey the abstract conceptual meanings and thus link the transcendent with experienced reality. Fager (1993:18) states: 'Again, we see a dialectic process in which humans both create the methods of mediating the meanings of the social world and are shaped by those methods of mediation.'

The ontological sub-structure that underpins the world's definition of reality also directly informs the life-world of the believers. Believers are called to live in 'this world'. This means that believers have to continue to structure their lives according to the way this world works. They have to accept and live within the socio-cultural definition of reality into which they were born. This definition of reality says that, in this world, one cannot walk on water, heal the blind or raise the dead directly by means of or in obedience to a 'word'. Instead, our words inter-act with the physical structure of reality as a given to create an experience of reality that is interpreted to construct a socio-cultural world of 'meaning', according to which we then shape our lives and actions.

The imperatives that confront us in Scripture (such as the claims of the Sermon on the Mount) claim absolute authority and demand absolute obedience. At the same time, they do not refer directly to this reality or world. They refer, first of all, to Jesus and the new reality in him. They flow from the indicatives, and the indicatives are statements about Jesus and what he has done in, through and with our reality. Until the return of Jesus, when he will finally change this reality forever, the new age is, therefore, reality. It is, however, a reality that is only accessible by faith in Jesus: It does not exist in and by itself; it cannot be realised in this world. Jesus as the last or final human presented an eschatological existence through his words and deeds. In him, the future was made present. Through his death and resurrection believers are invited to participate in this same eschatological existence. Willi Marxsen (1993) states:

Christianity deals with eschatological existence, more precisely, wherever eschatological existence happens we can call it Christian. The term eschatological is to be taken literally. The plural ta eschata means 'the last things', that is, the things that have to do with the turn of the aeon and whatever follows it. In apocalyptic thought this always means future things. Eschatological existence, however, always happens in the present. Thus people who are living eschatologically are anticipating the future. (p. 74)

As we have pointed out, this eschatological existence is not directly open to experience in the same way that the world is directly experienced. It is open to experience only indirectly, through faith in Christ. It is, however, marked by an expectation that, in future, it will be experienced directly. The church has to embrace the 'not yet' fully in order to do justice to the eschatological character of the new reality in Jesus. At the same time, she cannot relinquish the claim that Jesus has 'already' changed reality and that the believers are called to structure their lives according to the Kingdom that has come in Christ.

In practice, Christian believers have often sought to overcome the tension between the two domains (the new reality inaugurated in Christ and the old reality as defined by culture) by choosing for one domain at the expense of the other. Methodists, for instance, often contended that all true believers are able to live in, and according to, the domain of perfection whilst still within this world. According to them, the Christian life should, thus, be characterised by victory over sin and the world. This could, however, only be maintained by stripping the Biblical imperatives of their radical nature. Presbyterian believers, in contrast, often placed great stress on the inherent sinful nature of the believer and the brokenness of the world in which they live. This often led to a radically pessimistic view of this life, characterised by guilt, the threat of judgement and the confession of sin. This position often stripped the indicatives of their radical nature. Martin Luther wanted to maintain 
both realities. The only way that he could do so was by separating these two realities from each other. His doctrine of the 'orders' separated the 'spiritual or private order' from the 'secular or social order'. According to this view, the absolute imperatives of the Sermon on the Mount belong to the inner personal world of the believer (the spiritual order). It is not possible to act according to them in the public order (secular world), and the Christian must not even endeavour to do so. Luther insisted that the secular order (or government) is as much ordained by God as the spiritual Kingdom and that it should be allowed to operate according to its own rules to limit evil and do the will of God. This, ultimately, led to the place where the two orders - church or personal piety and the government or secular society - became radically isolated from each other. ${ }^{14}$

In his classic book, Christ and Culture, H. Richard Niebuhr (1951) distinguished five possible relationships between Christ and culture that ultimately determine Christian ethical behaviour: (1) Christ against culture - as found in 1 John, Tertullian and Tolstoy, (2) Christ of culture - as found in Locke, Ritschl, Rauschenbusch, (3) Christ above culture as found in Clement and Aquinas, (4) Christ and culture in paradox - as found in Paul, Luther and Kierkegaard and (5) Christ the transformer of culture - as found in the gospel of John. Niebuhr saw 'compromise' as the only way in which to deal with the tension between the 'already' and the 'not yet'. The ultimate perfection of love for everybody cannot be reached in this broken dispensation and believers thus have to settle for 'justice' as the only achievable form of this perfect love.

These different relationships between Christ and the world, and thus also the church and culture, need to be maintained simultaneously in such a way that they complement rather than exclude each other. The church's very existence presupposes a clash between different definitions of reality that contradict each other. Figure 1 illustrates the field of relativity generated by the eschatological claims of Christ upon this world.

Thesis one: The church and the Bible's claims to be absolute are relativised by Christ the living Lord. The Biblical injunctions in the Sermon on the Mount point to and are dependent on their relationship to Christ as the external reference of the text. (Arrows moving from 1-2 and 2-1): The underlying definition of reality (Number 1 - here called gospel indicative) which operates in Sermon on the Mount refers to the new age that has been inaugurated in Jesus (2) who through his resurrection from the dead stands outside of the text as the living Lord. The gospel indicative is relativised by its purpose, which is to bring about a living relationship with Jesus. The movement of the arrow from $2-1$ indicates

14.This led the church in Germany to accept the Nazi regime with the call for believers to obey the secular order that God has instituted in and through the state. Luther's insistence on the goal of the state - to bring about a society in which evil is curbed so as to make a peaceful life possible - and his stress on the need for 'love' to operate as the criterion for 'what is right' in both the secular and spiritual spheres should have been a limiting factor in the right for the state to do as it wished (see should have been a limiting factor in the
Thielicke \& Lazareth 1979:359-378). that Jesus is the same Jesus whom we meet in the text of the gospel. The work of the Holy Spirit in the church, indicated by the number (5) in the context of the church, is to focus our attention through the textual indicative (1) onto the living Lord (indicated by 2). The arrows from Christ (2) to the church (5) indicates that the church only exists as church through the presence of Christ as the Spirit within it.

Thesis two: The absolute demands in the Sermon on the Mount reflect the new creation and must be met in this world but are relativised because they are only met in Jesus, and outside of Jesus, they will only be met in the context of the new creation realised at his return. (Arrows moving from 1-3 and 3-1): The absolute imperatives (indicated by number 3 ) are relativised by the fact that they are always the result of the indicative of the new age (1) which is found in Jesus alone (2). They never operate in, of and for themselves but only refer back to Jesus.

Thesis three: The world can no longer exist as if Christ has not inaugurated a new creation. (Arrows moving from 3-4 and 4-3): The culture of the day (4) is relativised by the fact that God has inaugurated a new existence (1) which stands in direct opposition to the cultural interpretation of existence in this world. The way the world is in and of itself (4) is not the ultimate word on how it is in Jesus (1) and how it is to become (3) as a result of the actions of Jesus $(1,2)$.

Thesis four: Culture is a dynamic interpretation of reality and is thus always changing but remains constant in that it remains an interpretation of reality as an unchanging and unchangeable given. The church exists within this world and must operate according to the world. (Arrows moving between 4-6, 4-5): This indicates different ideologies struggling to become the dominant interpretation of reality. The church exists within and as part of the reality of the world outside of Christ (4-5).

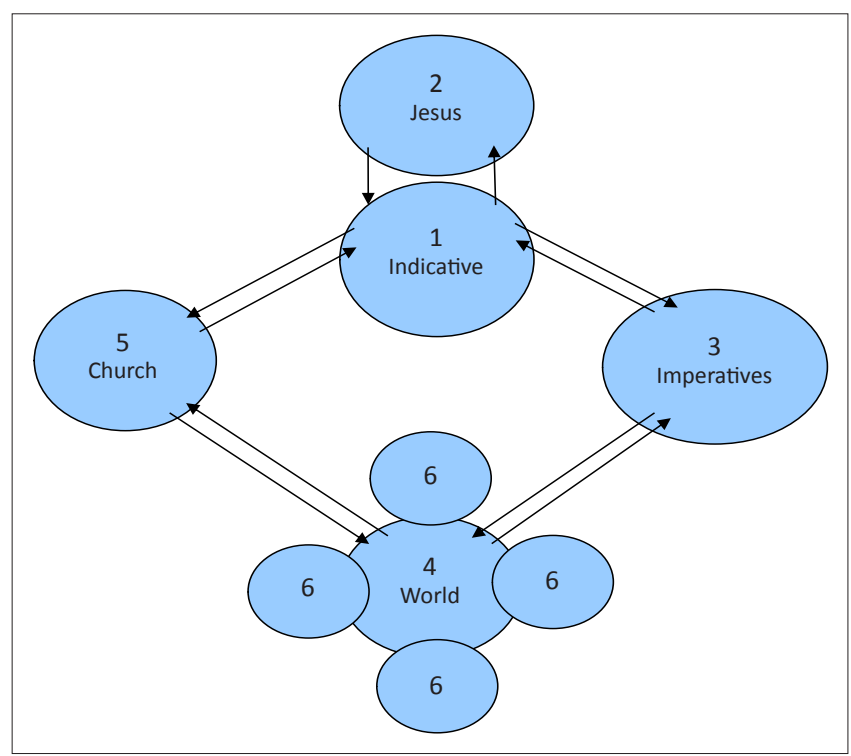

Source: Author's own creation

FIGURE 1: A model of radical ethical relativity. 
Thesis five: The church has to challenge the world's interpretation of existence through her obedient actions in order to reflect her faith commitment to the new creation in which she participates in Christ and which is made possible through the eschatological presence of the Spirit within her. (Arrows 5-2 and 5-4): The message of the new age (1) in Jesus (2) with its demand to live according to a new reality (3) instead of the reality interpreted by culture (4 and 6) calls the church to challenge the dominant culture in which she finds herself and to put up signs of the new creation within the old. The signs of the new creation are impossible within the world and are only made possible through the presence of the Spirit (2-5) in the church and by faith in Christ who has already made everything new.

\section{The church as a sub-culture marked by faith, hope and love}

The church exists within the limitations imposed by the present cultural context. The people in the church are the people of the world, unable to do the will of God. The church owns the brokenness of the world, defining itself as sinners saved by the gracious act of God in Christ alone. The difference between the church and the world is that the church knows and confesses that she is unable to live according to the absolute imperatives of God in this world and yet continues to stand under the calling to obey these imperatives because the grace of God has made her believers partakers of the Kingdom of light. In this sense, the church exists as a sub-culture with a counter-cultural agenda.

The presence of the Holy Spirit within the church points her to both the indicative of the Kingdom of which they are a part in Jesus and the world of the believers that still resists the Kingdom but that is nevertheless the object and focus of God's redeeming work. The church, in faith, cannot let go of either its new status in Christ or of its broken reality. The work of the Spirit forces the church constantly to challenge its world and its own inadequacy to do the will of God in the light of the message of Scripture. The church is not to seek a compromise with the world but to seek opportunities to radically do the will of God despite the structure of the world. The church is able to embrace these opportunities to live according to the new definition of reality in the light of the Kingdom both spontaneously, because of what she is in Christ and because the Spirit of Christ who lives within it, and in obedience to God's loving will and intention for the world.

The church, however, knows and confesses that she will only live fully in the new reality with the return of Christ. The church's acts of obedience by which she puts up signs of the new Kingdom of Love in this world is always marked by faith. Faith only operates where the impossibility of the event is fully accepted, but despite that, the new definition of reality in Christ is invoked. These works of faith are then miracles in the full sense of the word. The works as well as the effects of these works are transitory. They do not change the world completely but only point to the future when the Kingdom will finally be realised. The church is called to remain committed to the hope for this final future and also the hope for such miracles to continue to occur in the world. The church's existence as a community of love, the people of God, is a reality that she has to embrace by faith in Christ and in hope. The faith, hope and love of the church belong to the indicative of the gospel. The church is allowed to freely participate in faith, hope and love through the work of Christ and the presence of the Spirit. Faith, hope and love accompany the church as enduring eschatological signs of the new creation that the church knows will only be fully realised with the return of Christ.

It is clear from Figure 1 that the different relationships that Niebuhr had identified between Christ and culture all have their rightful place. The church in Christ is both beyond culture (2), against culture (3), a part of culture (5-4/4-5), in a paradoxical relationship to culture (4-5/2-3-5) and committed to transforming the existing culture as signs of the in-breaking of the Kingdom of God (5-2-3-4).

\section{Conclusion}

The church has always struggled to apply the Biblical ethical injunctions in the Sermon on the Mount directly to the life-world of believers. This life-world is the product of cultural formation which, in the church, takes place through her contemplation of the Biblical text in the light of her current context. Texts, however, may end up being used to maintain the dominant cultural world-view. The Biblical text can also become just another ideological tool in the battle for ideological dominance. Only when the church relinquishes her claim to possess absolute truth because of her faith in Jesus, her absolute Lord, is she able to take the world seriously. The 'world' as a socio-cultural definition of both an ontological given and a cultural interpretation of this givenness cannot accommodate any other claim to the absolute. In as much as Christians participate in the same ontological sub-structure of this broken world and interpret reality in the light of their own cultural definition of it, they are unable to live according to the imperatives of the gospel. In as much as Christians believe in the new existence in Christ, however, they are also unable to accept the world's definition of reality and participate in its modes of existence. In this article, a model is constructed to show how the radical eschatological 'relativisation' of everything that is considered 'absolute' in the light of the Lordship of Christ enables the church to develop a critical sub-culture that is simultaneously against, for, above, paradoxical to as well as the transformer of the dominant culture through its obedient actions marked by faith, hope and love.

\section{Acknowledgements Competing interests}

The author declares that he has no financial or personal relationship(s) that may have inappropriately influenced him in writing this article. 


\section{References}

Barth, K., 2004, Church dogmatics: The doctrine of the Word of God, vol. 1, Part 2: The revelation of God; Holy Scripture: The proclamation of the Church, Continuum International Publishing Group, London.

Berger, C.R., Roloff, M.E. \& Ewoldsen, D.R., 2009, The handbook of communication science, SAGE, Thousand Oaks, CA.

Berger, P.L. \& Luckmann, T., 2011, The social construction of reality: A treatise in the sociology of knowledge, Open Road Media, New York, NY.

Bloom, H., 2004, EPZ deconstruction and criticism, Continuum International Publishing Group, London.

Dockery, D.S., 2000, Biblical interpretation then and now: Contemporary hermeneutics in the light of the early church, Baker Book House, Grand Rapids, MI.

Dorr, D.R., Graham, D.B. \& Koch, B.A., 1999, Perspectives on the World Christian Movement: A reader, Authentic Media, Milton Keynes, UK. PMCid:PMC2014214

Edwards, D., 1996, 'Christ and Culture - some preliminary reflections', Colloquium $28(2), 84$.

Fager, J.A., 1993, Land tenure and the Biblical jubilee: Uncovering Hebrew ethics through the sociology of knowledge, Continuum International Publishing Group, London, UK.

Gadamer, H.G., 2004, Truth and method, Continuum International Publishing Group, London.
Giles, H., Coupland, J. \& Coupland, N., 1991, Contexts of accommodation: Developments in applied sociolinguistics, Cambridge University Press, Cambridge, UK. http://dx.doi. org/10.1017/CBO9780511663673

Goffman, E., 1974, Frame analysis: An essay on the organization of experience, Harper \& Row, London.

Hall, S., Lowe, A., Hobson, D. \& Willis, P., 2004, Culture, media, language: Working papers in cultural studies, 1972-79, Routledge, Abingdon, Oxon, UK.

Hays, R., 1996, The moral vision of the New Testament: Community, cross, new creation: A contemporary introduction to New Testament ethic, HarperCollins, San Francisko, CA.

Kincaid, D.L., 1987, Communication theory: Eastern and western perspectives, Academic Press, Waltham, MA.

Littlejohn, S.W. \& Foss, K.A., 2008, Theories of human communication, Cengage Learning, Stamford, CT.

Marxsen, W., 1993, New Testament foundations for Christian ethics, Alban Books Limited, Edinburgh, UK.

McKim, D.K., 1999, A guide to contemporary hermeneutics: Major trends in Biblical interperation, Eerdmans, Grand Rapids, MI. PMCid:PMC1460643

Niebuhr, H.R., 1951, Christ and culture, Harper \& Row, London, UK.

Ricoeur, P., 1976, Interpretation theory: Discourse and the surplus of meaning, TCU Press, Fort Worth, TX.

Thielicke, H. \& Lazareth, W.H., 1979, Theological ethics: Politics, Eerdmans, Grand Rapids, MI. 